\title{
14
}

\section{THE WASTE WATER TREATMENT SITUATION IN THE FORMER GERMAN DEMOCRATIC REPUBLIC}

\author{
Manfred Lohse \\ Dr. Friman \& Partner GmbH, Belzig
}

Germany

\begin{abstract}
It is well known that the Federal Republic of Germany (FRG) and the German Democratic Republic (GDR) have reunited. The new federal states with about 17 millions inhabitants are: East-Berlin, Brandenburg, Mecklenburg-Vorpommern, Sachsen, Sachsen-Anhalt and Thüringen. This paper (talk) begins with a description a of the sewage disposal situation at the time of the reunion and then goes on to discusses the improvements that will have to be made. Finally a few examples of the situation in the cities and rural areas will be presented.

\section{THE SITUATION IN THE FORMER EASTERN GERMANY BEFORE 1990}

The sewage disposal situation was analysed in the years 1990 and 1991. The main recipients of treated effluent are the rivers Elbe flowing into the North Sea, the Oder/Neiße river and several smaller waters flowing into the Baltic Sea (see table 1). The international contracts on water pollution control of the North Sea and the Baltic Sea concern all the new federal states of Germany. For example, the considerable pollution loads of the river Elbe are listed in table 2.
\end{abstract}


Table 1: Main drainage areas [11, changed]

\begin{tabular}{|l|c|c|}
\hline \multicolumn{1}{|c|}{ river } & area [\%] & inhabitants [\%] \\
\hline flowing to the North Sea & & \\
Elbe & 72.9 & 82.2 \\
Werra, Aller, Leine & 5.5 & 4.9 \\
\hline flowing to the Baltic Sea & 21.6 & 12.9 \\
especially Oder/Neiße & & \\
\hline \hline
\end{tabular}

Table 2: Pollution load in the Elbe near Boizenburg, 1989 [4]

\begin{tabular}{|l|r|r|}
\hline mean water flow & 613 & $\mathrm{~m}^{3} / \mathrm{s}$ \\
\hline $\mathrm{COD}$ & 651000 & $\mathrm{t} / \mathrm{a}$ \\
\hline $\mathrm{BOD}_{5}$ & 102000 & $\mathrm{t} / \mathrm{a}$ \\
\hline $\mathrm{NH}_{4}-\mathrm{N}$ & 36700 & $\mathrm{t} / \mathrm{a}$ \\
\hline $\mathrm{PO}_{4}-\mathrm{P}_{\text {wbole }}$ & 9300 & $\mathrm{t} / \mathrm{a}$ \\
\hline chloride & 3500000 & $\mathrm{t} / \mathrm{a}$ \\
\hline lead & 120 & $\mathrm{t} / \mathrm{a}$ \\
\hline cadmium & 13 & $\mathrm{t} / \mathrm{a}$ \\
\hline chrome & 280 & $\mathrm{t} / \mathrm{a}$ \\
\hline copper & 380 & $\mathrm{t} / \mathrm{a}$ \\
\hline nickel & 270 & $\mathrm{t} / \mathrm{a}$ \\
\hline mercury & 23 & $\mathrm{t} / \mathrm{a}$ \\
\hline zinc & 2800 & $\mathrm{t} / \mathrm{a}$ \\
\hline
\end{tabular}

Even the big cities only had primary or extremely overloaded biological purification stages. Since the 1990's the enormous pollution of the surface waters has been considerably reduced by the closure of factories and the construction of new sewage reatment plants.

The former failures of sewage disposal become clear when looking at the degree of connection to sewerages in the urban areas (see table 3). 
Table 3: Degree of connection in 1989 in [\%] of inhabitants [4]

\begin{tabular}{|l||c|c|c|}
\hline district & drinking water net & sewerage & $\begin{array}{c}\text { sewage treatment } \\
\text { plant }\end{array}$ \\
\hline Berlin-East & 99.9 & 97.0 & 97.0 \\
\hline Cottbus & 95.8 & 58.8 & 56.4 \\
\hline Chemnitz & 94.7 & 78.3 & 49.9 \\
\hline Dresden & 91.0 & 68.6 & 57.4 \\
\hline Erfurt & 91.6 & 76.6 & 52.0 \\
\hline Frankfurt/Oder & 91.9 & 56.1 & 56.1 \\
\hline Gera & 98.5 & 85.2 & 49.6 \\
\hline Halle & 95.0 & 69.7 & 53.0 \\
\hline Leipzig & 95.1 & 81.2 & 64.6 \\
\hline Magdeburg & 89.8 & 78.9 & 60.0 \\
\hline Neubrandenburg & 95.6 & 62.0 & 55.5 \\
\hline Potsdam & 80.5 & 50.6 & 50.5 \\
\hline Rostock & 94.8 & 74.1 & 69.2 \\
\hline Schwerin & 99.1 & 57.6 & 51.4 \\
\hline Suhl & 99.9 & 73.2 & 33.9 \\
\hline Summary & 93.3 & 59.2 & \\
\hline
\end{tabular}

The following table shows the relationship between the inhabitants (without industry effluent) and the different methods of sewage purification (see table 4):

Table 4: Extent of sewage purification in 1989 [4]

\begin{tabular}{|l||c|c|}
\hline purification method & inhabitants [E] & part [\%] \\
\hline \hline none & 2500000 & 15 \\
\hline soil infiltration & 1600000 & 10 \\
\hline individual sewage treatment plant & 3000000 & 18 \\
\hline primary treatment (mechanical) & 3700000 & 22 \\
\hline secondary treatment (biological) & 5900000 & 35 \\
\hline \hline
\end{tabular}

Every year about 4000 million mé of industrial effluent for the most part only inadequately purificated or even untreated was discharged into the rivers and other waters. 
The following table displays the estimated investment need to modernise the whole waste water treatment system (table 5):

Table 5: Investment needed to MODERNISE the whole waste water treatment system [12]

\begin{tabular}{||l|c|c|}
\hline raising the degree of connection from 58 to $87 \%$ & 10.4000 million DM & $19.7 \%$ \\
\hline sewerage restoration & 20.0000 million DM & $37.9 \%$ \\
\hline new primary treatment capacity & 5.9000 million DM & $11.2 \%$ \\
\hline new basic biological purification capacity & 8.9000 million DM & $16.9 \%$ \\
\hline new advanced purification capacity $(\mathrm{N}+\mathrm{P})$ & 7.6000 million DM & $14.4 \%$ \\
\hline total & $\mathbf{5 2 . 8 0 0 0}$ million DM & $\mathbf{1 0 0 . 0} \%$ \\
\hline
\end{tabular}

On the whole there're the following requirements:

- construction of approximately $6200 \mathrm{~km}$ of sewerage

- repair of about $7400 \mathrm{~km}$ of sewerage (about 2/3 of the existing sewerage pipes are damaged)

- creation of a rain water treatment concept

- increase of the degree of connection to the sewage treatment system from 58 to $90 \%$

- construction of 8 plants to treat more than 20000 population equivalents (E) of sewage

- construction of 1000 to 2000 sewage treatment plants in about 6000 communities with more than $2000 \mathrm{E}$

- repair and enlargement of existing sewage plants, showing the following faults: old fashioned machinery, hydraulically overloaded, overloaded biological purification, defect equipment, corrosion of concrete, missing mechanical sludge dewatering, insufficient sludge stabilisation [11].

The main industrial regions of the former German Democratic Republic had developed to regions of ecological crisis. The main industrial regions are: Leipzig/Bitterfeld/Halle/Merseburg with it's chemical industry and it's quarrying and processing of brown coal, the Mansfelder Land with numerous copper works, the mining and energy region of Niederlausitz, the uranium mining region in Sachsen and Thüringen and the coastal region of Mecklenburg-Vorpommern. The restoration and modernisation of the worst sources of contamination, which were confined to small areas, had priority. 


\section{LEGAL PRECONDITIONS}

\section{Water Legislation}

Because Germany is a federal republic, each state has to have it's own legislation, which is based upon the federal laws. The new states of eastern Germany need three or four years, until they had made their own water laws and ordinances.

\section{Management Structures}

Until the 1980's, in the older states of Germany, the management of sewage treatment plants was either in the hands of functional associations, acting on behalf of the local municipalities, or they were directly state-owned. This is because the local authorities are committed by public law with the management of sewage. Since the middle of the 1980's the management has been transferred to independent public bodies called Eigenbetriebe, that have their own budget. Some of the treatment plants have been complete or partly privatised. After the necessary legislation had been passed in the new states, these different forms of management were adopted in such a way as to reduce the costs of the many modernisation projects. An over view of the jurisdiction of sewage management are listed in table 6.

Table 6: Jurisdiction of sewage management in the federal republic of Germany [15; changed]

\begin{tabular}{|c|c|c|c|c|c|}
\hline \multicolumn{2}{|c|}{ civil law } & \multicolumn{4}{|c|}{ public law } \\
\hline $\begin{array}{l}\text { private compa- } \\
\text { nies:limited } \\
\text { company,jo- } \\
\text { int-stock com- } \\
\text { pany, limited } \\
\text { partnership }\end{array}$ & $\begin{array}{c}\text { participation } \\
\text { in a private } \\
\text { company }\end{array}$ & $\begin{array}{c}\text { works with a } \\
\text { municipal } \\
\text { budget }\end{array}$ & $\begin{array}{l}\text { works with a } \\
\text { municipal } \\
\text { budget }\end{array}$ & $\begin{array}{l}\text { functional } \\
\text { association }\end{array}$ & $\begin{array}{l}\text { public law } \\
\text { contracts }\end{array}$ \\
\hline \multicolumn{2}{|c|}{$\begin{array}{l}\text { legally and economically } \\
\text { independent }\end{array}$} & \multicolumn{2}{|c|}{$\begin{array}{l}\text { legally and economically } \\
\text { dependant }\end{array}$} & $\begin{array}{l}\text { fusion of mu- } \\
\text { nicipalities } \\
\text { with new le- } \\
\text { gal status }\end{array}$ & $\begin{array}{l}\text { transfer of re- } \\
\text { sponsibility to } \\
\text { others munici- } \\
\text { palities }\end{array}$ \\
\hline
\end{tabular}




\section{CHANGING CONDITIONS}

\section{General Improvements}

During the period of 1990 to 199440000 million DM, provided by different national and international aid programs, were spent on environmental protection. This includes remediation of contaminated sites and air control.

The water quality of lakes and rivers has improved considerably, since these measures were initiated. During 1989 to 1993 there was a important reduction of contaminants in the river Elbe [5]:

- cadmium from 0.45 to $0.32 \mathrm{mg} / \mathrm{l}$

- mercury from 0.78 to $0.11 \mathrm{mg} / \mathrm{l}$

- adsorbable organically bound halogens (AOX) from 100 to $60 \mathrm{mg} / \mathrm{l}$.

The rivers showed a general decrease in ammonium and phosphorous content, accompanied by a rise in oxygen. The sale of phosphate free detergents caused a $42.86 \%$ reduction of the Phosphate load discharged by municipal sewage plants. This represents 8000 metric tons of Phosphate as opposed to 14000 metric tons per year.

The measures are not yet complete. In 1995 the German federal government decided to allocate 6600 million DM per year for a period of ten years. In addition, the European Union contributes about 27000 million DM per year and will continue to do so until 1999[5]. At the beginning of 1994, thirty-one new sewage plants costing a total of 3000 to 4000 million DM were completed or were under construction.

The discussion of waste water management is often subjective and many people tend only to see the high costs that involved. Few realise how much has been accomplished by the investments. Here are few examples of the successes of the German federal states Brandenburg, Mecklenburg-Vorpommern and SachsenAnhalt.

\section{Example Brandenburg}

The amount of households connected to the sewerage system rose regionally in the years from 1990 to 1995 from $53.5 \%$ to $60 \%$. There's still a large difference between rural and urban areas. While $40 \%-60 \%$ of country households are connected to sewers, more than $96 \%$ are connected to the sewers in the cities. The water quality has improved in most lakes and rivers.

In 1990 not one sizeable sewage plant complied to the technical standards set by federal legislation (WHG). By 1996 three quarters of the 102 sewage plants each built for population equivalents of over 5000 were able to reduce the amount of nutrients and abide by the regulations [1]. 


\section{Example Mecklenburg-Vorpommern}

During 1990 to 1996 two hundred and twenty sewage plants were newly constructed or enlarged. This is shown by the following table.

Table 7: Amount of newly constructed or enlarge dsewage Plants from 1990 to 1996 in Mecklenburg-Vorpommern [13]

\begin{tabular}{|l|c|c|c|c|c||}
\hline \hline $\begin{array}{l}\text { pollution } \\
\text { equivalents }\end{array}$ & $<1000 \mathrm{E}$ & $\begin{array}{c}1000- \\
5000 \mathrm{E}\end{array}$ & $\begin{array}{c}5000- \\
20000 \mathrm{E}\end{array}$ & $\begin{array}{c}20000 \\
100000 \mathrm{E}\end{array}$ & $>100000$ \\
\hline amount & approx. 130 & 44 & 26 & 17 & 3 \\
\hline
\end{tabular}

Since 1993 the quality of inshore and coastal waters has been under observation. A network of monitoring stations and a number of different projects to establish the quality of flowing waters, lakes, coastal waters and groundwater have been created. They mainly involve :

- optimisation of the monitoring network to record data on rivers and coastal waters

- enhanced surveillance of lakes with surveys of the condition of 600 lakes larger than 10 ha

- construction of a new network to monitor the groundwater

- extension of the amount of different assayed substances by including heavy metals, organic industrial chemicals, pesticides, complexes, and polycycilic aromatic hydrocarbons (PAH) to the parameter spectrum of the investigation programs

- investigation of sediments in rivers, lakes and coastal waters

- preparation of a biological monitoring program involving the determination of the contaminant intake of the Biota Bivalve and a survey of the macozoobenthos and macrophyten

The rivers are in the following condition:

- Owing to higher oxygen content and less organic matter, about $70 \%$ of the rivers reached a quality grade of 2 in 1995. This was due to improved sewage treatment and a decline in the surface run-off of agricultural nutrients.

- The introduction of third stage precipitation units in sewage plant has reduced the phosphate discharge, thus decreasing the phosphate content of rivers. The utilisation of phosphate free detergents and less direct intake of agriculturally related phosphate has also resulted in less pollution (table 8). Consequently, the contamination of the Baltic Sea along Mecklenburg-Vorpommern's coast sank considerably. Before 1990 the discharge of ortho phosphate from inshore waters into the Baltic Sea amounted to 330 metric tons/year. By 1994 it sank to $200 \mathrm{t} / \mathrm{a}$. The increase during 1993 and 1994 is the result of high pre- 
cipitation rates accompanied by high mean run off. The phosphate load in the outlets of the sewage plants have decreased to a level of $20 \%$.

Table 8: Ortho-phosphate discharge from Mecklenburg-Vorpommern's inshore waters into the Baltic Sea [13]

\begin{tabular}{|c|c|c|c|c|c|c|c|c|c|c|c|}
\hline year & 1984 & 1985 & 1986 & 1987 & 1988 & 1989 & 1990 & 1991 & 1992 & 1993 & 1994 \\
\hline $\begin{array}{c}\text { discharge } \\
\text { [t/a] }\end{array}$ & 290 & 3010 & 370 & 330 & 310 & 320 & 350 & 230 & 160 & 190 & 220 \\
\hline
\end{tabular}

- The inshore waters have a tendency towards declining ammonium- and increasing nitrate content, that mainly diffusely flows into the rivers via agricultural irrigation. There's a close relationship between precipitation, the resulting surface run off and nitrate loads.

- Heavy metals, industrial organic compounds and pesticides are either undetectable or only present in very small concentrations. Only occasionally are the concentrations higher than the dictated limits.

- After the sewage treatment plant in Stralsund went into operation the prolonged prohibition for sea side bathers was lifted.

Sixty four sewage plants in Mecklenburg-Vorpommern, each managing sewage equivalent to a population of over 10000 (E), are affected by the European legislation concerning the treatment of municipal effluent. By 1998, due to modemisation, these plants will largely abide by the regulations. Additionally more than $80 \%$ of the households are connected to the municipal sewerage. Thus, the sewerage can be expected to conform with legislation within the next 10 years.

\section{Example Sachsen Anhalt}

During 1990 to 1996 one hundred and seventy five biological sewage plants, 64 containing phosphorus and nitrogen elimination units, were erected in SachsenAnhalt. All in all 390 municipal effluent treatment plant were in operation by the end of 1996 [3]. The improvements between 1990 and 1996 are shown in the following table. 
Table 9: The development of municipal sewage treatment in sachsen-anhalt in relation to it's population. [14]

\begin{tabular}{|l|c|c|}
\hline \multicolumn{1}{|c|}{ year } & 1990 & 1996 \\
\hline inhabitants & approx. 2.9 million & approx. 2.8 million \\
\hline decentral treatment (catch pits) & $14.8 \%$ & $7.5 \%$ \\
\hline degree of connection to a sewerage & $66.1 \%$ & $76.2 \%$ \\
\hline degree of connection to sewage plants & $56.1 \%$ & $73.9 \%$ \\
\hline amount sewage plants & 287 & 391 \\
\hline primary clarification & $51.1 \%$ & $31.6 \%$ \\
\hline biological purification & $33.6 \%$ & $22.5 \%$ \\
\hline further purification & $0.5 \%$ & $38.3 \%$ \\
\hline
\end{tabular}

The success of the measures are reflected by the decline of contaminate loads in inshore waters. The following table display the exceptionally good figures of the Elbe.

Table 10: Contamination of the river Elbe (without the rivers Mulde and Saale) in sachsen -Anhalt [3]

\begin{tabular}{|c|c|c|c|c|c|}
\hline \multicolumn{6}{|c|}{ Municipal Discharge } \\
\hline year & $\begin{array}{c}\mathrm{COD} \\
\mathrm{t} / \mathrm{a}\end{array}$ & $\begin{array}{c}\mathrm{BOD}_{s} \\
\mathrm{t} / \mathrm{a}\end{array}$ & $\begin{array}{c}N_{\text {marg lool }} \\
t / a\end{array}$ & $\begin{array}{c}P_{\text {towa }} \\
t / a\end{array}$ & $\begin{array}{c}{ }^{* A O X} \\
t / a\end{array}$ \\
\hline 1992 & 11127 & 6192 & 1305 & 176 & 2.62 \\
\hline 1993 & 8863 & 4735 & 1053 & 139 & 2.51 \\
\hline 1994 & 7368 & 3845 & 1147 & 135 & 2.80 \\
\hline 1995 & 4746 & 2431 & 982 & 77 & 2.30 \\
\hline \multicolumn{6}{|c|}{ Industrial Discharge } \\
\hline year & $\begin{array}{c}\mathrm{COD} \\
\mathrm{t} / \mathrm{a}\end{array}$ & $\begin{array}{l}\mathrm{Hg} \\
\mathrm{t} / \mathrm{a}\end{array}$ & $\begin{array}{c}\mathrm{N}_{\text {inorg.toon. }} \\
\mathrm{t} / \mathrm{a}\end{array}$ & $\begin{array}{l}P_{\text {towal }} \\
t / a\end{array}$ & $\begin{array}{c}* A O X \\
t / a\end{array}$ \\
\hline 1992 & 5.639 & 0.0005 & 1.699 & 60 & 2.09 \\
\hline 1993 & 3.379 & 0.0002 & 302 & 63 & 0.83 \\
\hline 1994 & 1.258 & 0.0007 & 290 & 15 & 0.50 \\
\hline 1995 & 463 & 0.0003 & 101 & 10 & 0.05 \\
\hline
\end{tabular}

* adsorbable organically bound halogens 
About 3000 million DM were invested, whereby approximately 0.75 million DM were provided by the state of Sachsen-Anhalt. Required are an additional 6000 million DM, of which 1600 million DM are to be invested in the construction and modernisation of sewage plants and 4.4 million DM in municipal sewerage networks and their connecting mains.

\section{PROJECT EXAMPLES}

The following projects have been chosen to demonstrate how solutions can be found for each special case. These examples have been selected:

- Sewage plant Dessau. It displays quickly changing conditions (population: $350000 / 185000$ ).

- Sewage plant Gotha representing urban conditions (population: 150000).

- Sewage plant Bitterfeld-Wolfen, which is strongly influenced by it's industrial surroundings (population: 422000).

- The small town Belzig representing rural conditions (population: 11000)

\section{Project Dessau}

The planning of the new sewage plant Dessau shows how euphoric the assessment of the economic development after the reunion of east and west was. Dessau is a town on the Elbe with a population of about 100000 . It is characterised by the machine tool, chemical, sugar, and yeast industries.

In March 1991 an engineering office was commissioned with the planning of a sewage plant for Dessau. It was based on a future population of 350000 at a cost of 250 million DM. When the preliminary planning was received in November 1991 it calculated a population of 300000 and investment of 200 million DM. In the following months it became clear that economic growth would not be so great as expected. The plan which followed in August 1992 recommended a primary clarification for a population of 230000 and an investment of 180 million DM. Further estimates of the economic development were made, stipulating a primary clarification for a population of 185000 at a cost of 100 million DM. A commission in July 1994 to arrange the advertisement was based on an investment of 90 million. Finally at the end of 1994 the commission was awarded to a firm for the sum of 78 million.

The sewage plant started operating in June 1997 and contains a primary clarification, consisting of belt screens, grit separator, grease separator and a preliminary settling tank. The biological treatment entails a nitrification, denitrification and phosphorus elimination in an activated sludge tank and secondary settling tank. A micro-strainer follows in a final stage. The sewage sludge is anaerobicly treated and dried. The resulting gas is used to fuel a heating power station. The sewage sludge can be utilised agriculturally as compost, be incinerated or deposited, depending on demand. The water quality applies with European regulations [2]. 


\section{Project Gotha}

Until the German reunion Gotha had primary clarification tanks, which were installed in 1960, and a well functioning trickling filter dating back to 1910. The incoming pollution load of 190000 population equivalents $(E)$ had to be dealt with by the mechanically operating plant designed for a capacity of only $130000 \mathrm{E}$. The sewage of 56000 inhabitants and the effluent of food industries producing vegetables, meat, fat, emulgators and milk had to be treated. Since 1939 the sewage sludge was treated in a heated digestor. After 1960 this was complimented by an open earth basin to stabilise the sludge. All the buildings were derelict. Because, in March 1990, the plant failed to function, plans for new installations were commissioned in May 1990. This was at a time just before the currency union. In January 1991 a general contractor was commissioned with the construction of a new plant with the prerequisite to deliver the blue prints within 6 months and to complete the project within two years. The plant, that was constructed to achieve the contemporary threshold values, had the capacity to treat 150000 population equivalents, including the sewage from 22 neighbouring villages.

Table 11: Threshold values of the Sewage plant Gotha [10]

\begin{tabular}{||c|c|c||c||c||}
\hline $\begin{array}{c}\mathrm{BOD}_{\mathrm{s}} \\
\mathrm{mg} / \mathrm{l}\end{array}$ & $\begin{array}{c}\mathrm{COD} \\
\mathrm{mg} / \mathrm{l}\end{array}$ & $\begin{array}{c}\mathrm{NH}_{4}-\mathrm{N} \\
\mathrm{mg} / \mathrm{l}\end{array}$ & $\begin{array}{c}\mathrm{P}_{\text {toal }} \\
\mathrm{mg} / \mathrm{l}\end{array}$ & $\begin{array}{c}\mathrm{N}_{\text {inorg. }} \\
\mathrm{mg} / \mathrm{l}\end{array}$ \\
\hline 15 & 75 & 10 & 1 & 18 \\
\hline
\end{tabular}

In November 1991, after nine months construction the primary clarification was ready for operation. Twenty four months past before the test phase commenced The plant consists of the following installations [16]: coarse screen $(80 \mathrm{~mm})$, fine screen $(10 \mathrm{~mm})$, storm-water stand-by tank, aerated grit removal tank, preliminary clarification (50 minutes at storm conditions and 25 minutes under normal circumstances), Bio-P-tank (1.8 hours contact time by dry weather), meander tanks for simultaneous nitrification/denitrification (sludge 16 days old, almost continuously variable from aerobic to anoxic to anaerobic zones). intermediate settling, chemical precipitation, secondary clarification using laminar separators, digestor start-up, sludge densifier (filter drums), digestion tank (33 to $37^{\circ} \mathrm{C}$ ), secondary consolidation, sludge preparation, compartment type filter press and digest gas storage tank, desulphuration, heating power station. The plant possesses a micoelectronic operation control system. 


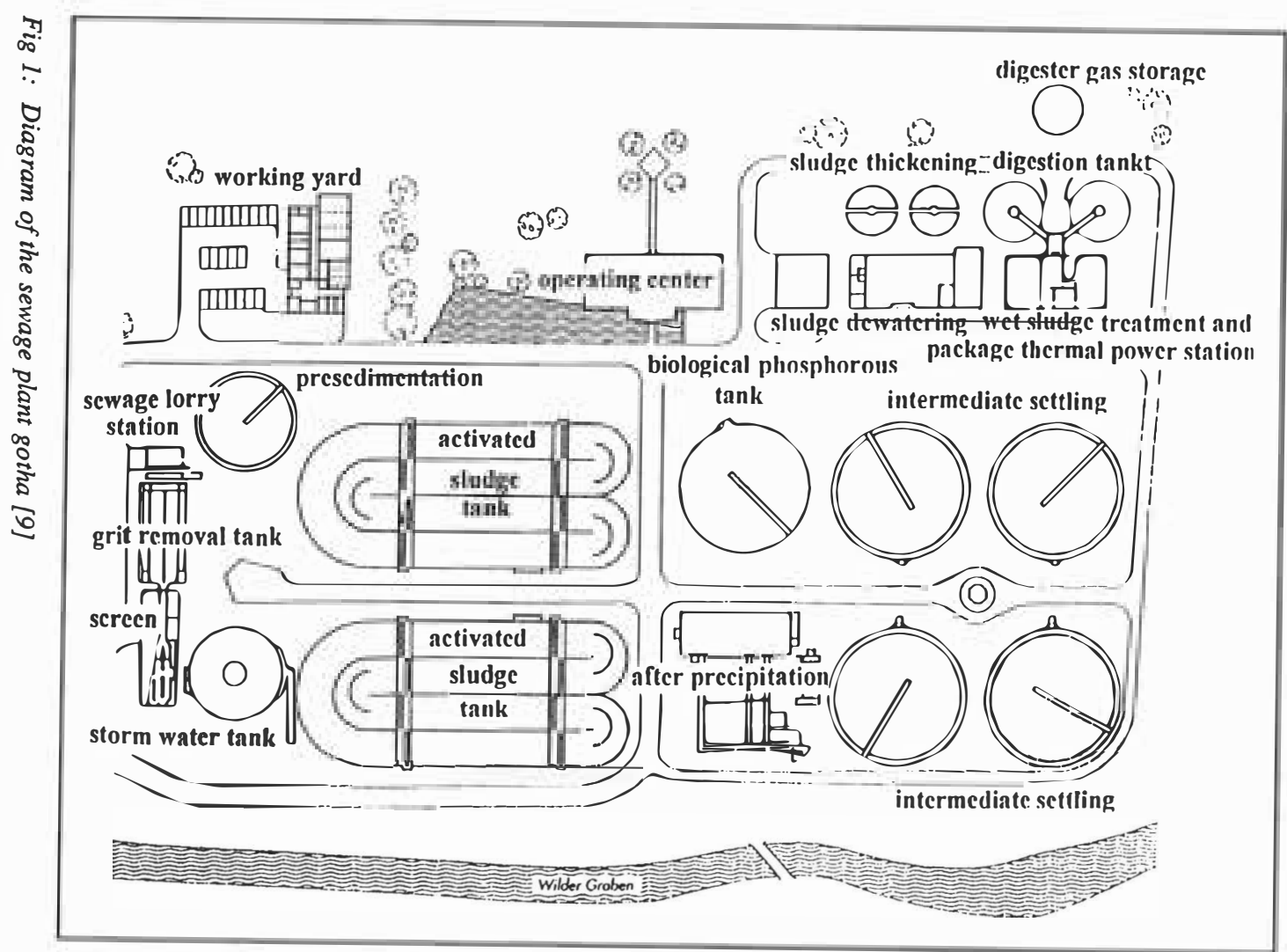


The total nitrogen concentrations of the outlet are plotted as a summation curve for one operational year. The degree of effectivity of the $\mathrm{N}$-elimination lies at $88 \%$. In spite of extreme feed fluctuations, on account of discontinuous flows of faeces, which is a typical situation in the new federal states, the mean concentration in a two hour composite sample lies below $4 \mathrm{mg} / \mathrm{l}$ with maximum values of upto $13 \mathrm{mg} / \mathrm{l}$. A maximum value of $11.9 \mathrm{mg} / \mathrm{l}$ (maximum ammonium helium 3.6 $\mathrm{mg} / \mathrm{l})$ was assayed in the year 1996 [8].

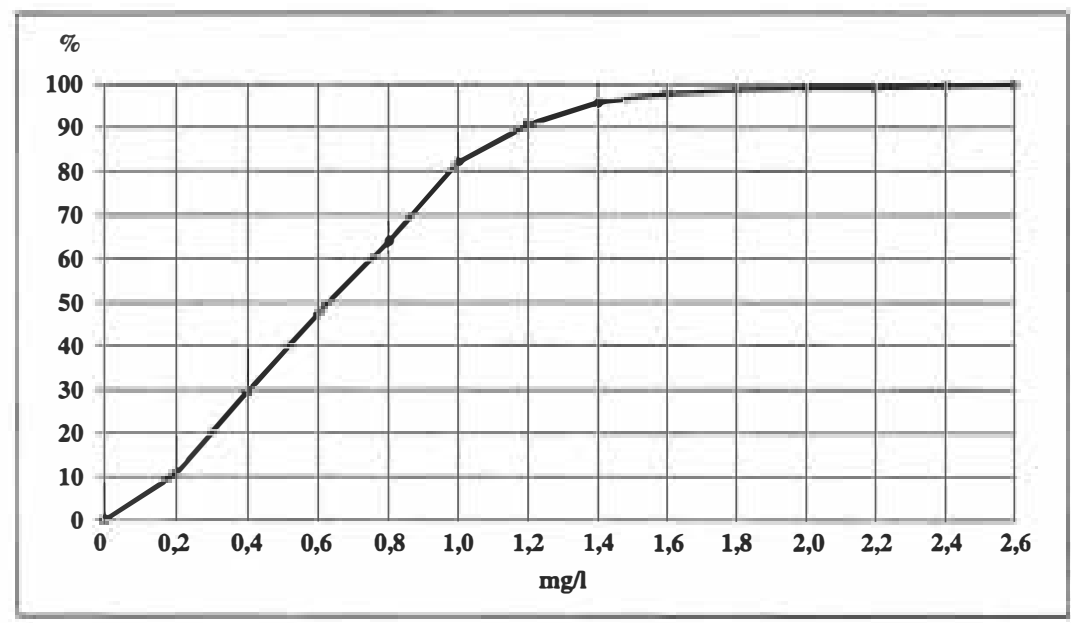

Fig 2: Cumulative frequenzy of ammonium Nitrogen discharged by the sewage plant gotha in 1994 [9]

The supply conditions are not appropriate for biological phosphate elimination, due to the total phosphorus input concentrations oscillating between 5 and 20 $\mathrm{mg} / \mathrm{l}$. Furthermore the Ptotal/BOD5 ratio of 0.08 is unsuitable. However, the biological elimination on it's own without precipitation produces a total phosphorus discharge of below $0.5 \mathrm{mg} / \mathrm{l}$ (degree of efficiency $98.5 \%$ ), thus making a secondary precipitation unnecessary.

The total net investment of 77.6 million DM (517 DM/E) divides up into 41.9 million DM for construction work, 29.8 million DM for plant machinery, 4.6 million DM for fees and 4.6 million DM for others (development and real estate). The state of Thüringen and the federal environment ministry provided 19.7 million DM $[9,16]$. 


\section{The Joint Venture Sewage Plant Bitterfeld-Wolfen}

This project represents the co-operation of the municipality and industry in an region, that is strongly influenced by the production of chemicals and photographic products. The construction of the joint sewage plant fulfilled one of the requirements for upholding and developing industrial growth in the area of Bitterfeld-Wolfen. A former state owned chemistry corporation (Chemiekombinat) was split up in 1990 and transformed into a 600 ha large chemistry park. The sequence of development was as follows:

- April 1990: construction and operation of a pilot plant

- March 1991: commissioning of subcontractors by the general contractor

- September 1991: commissioning of the application for permits

- October 1991: foundation of an limited company (52\% belonging to 2 co-operative sewage associations and $48 \%$ to the chemical industry)

- November 1991: submitting of the application papers.

- November 1991: submitting of an environmental compatibility test

- January 1992: commissioning of the detail planning

- June 1992: permission granted by the water authorities for construction and operation

- July 1992: construction begins

- December 1993: operation of parts of the plant

- August 1994: completion of construction and acceptance of the plant

The plant is designed for a population equivalent of $422000 \mathrm{E}$ with a feed of $77000 \mathrm{me} / \mathrm{d}$ or $4800 \mathrm{me} / \mathrm{h}$ respectively. Between the planning stage and completion of the plant a considerable decline in growth of the chemical industry took place; commercial areas failed to develop as expected. In addition the integration of several communities into the sewerage had been delayed. Nevertheless, owing to the damaged sewerage, that has not yet been repaired, extra material enters the system, causing the plant periodically to operate at $100 \%$ of it's capacity.

The investment for the sewage treatment installation (without sludge processing) amounts to 226 million DM. A further approximate 83 million DM were spent on pump stations, pressure and delivery conduits.

The industrial effluent reaches the plant via 10 pressure pipe-lines or by tanker vehicle and is mixed in tank to uniform it. Using lime-slurry, iron chloride $(\mathrm{FeCl} 3)$ and polyelectrolyte solutions it under goes coagulation and precipitation, removing mainly phosphate and heavy metals. If problems occur the effluent can be transferred to an emergency tank. Dyed effluent is separately prepared and added to the waste water, which is then treated further with an iron sulphate solution and lime slurry until the colouring disappears. 
The municipal effluent is conventionally preclarified as follows: submersible motor pump station, screen with $10 \mathrm{~mm}$ band distance, aerated grit removal tank and grease separator, fine screen with $2 \mathrm{~mm}$ band distance, and mixing tank.

The municipal effluent as well as the industrial effluent is treated in slightly contaminated $\mathrm{BIOHOCH}$-reactors, which functions as follows:

- enhanced elimination of the industrial effluent's remaining resistant substrate, if necessary by adding activated charcoal

- nitrification/denitrification of the industrial effluent by employing a certain amount of decomposable municipal sewage

- enhanced elimination of the sewage's contaminants by nitrification/ denitrification

- phosphorus elimination via precipitation with iron III chloride

A BIOHOCH-reactor consists of a cylindrical centre piece, that's attached to the denitrification unit. The centre piece, forming an activation compartment, is divided by a horizontal perforated metal sheet into two sections, the lower for aeration and the upper for degassing using (Blasenabscheidern). Radial air jets create the aeration. A ring shaped secondary clarifier is mounted around the top part of the centre piece.

The separated sludge is dehydrated to about 5-6\% water content in a screw densifier and transported to a sludge tank, to which grease, originating from the municipal sewage and industrial effluent's precipitate, is added. After further dehydration in a centrifuge the sludge is finally treated with lime and deposited. The use of a land fill is a temporary measure until an incineration plant is built. 


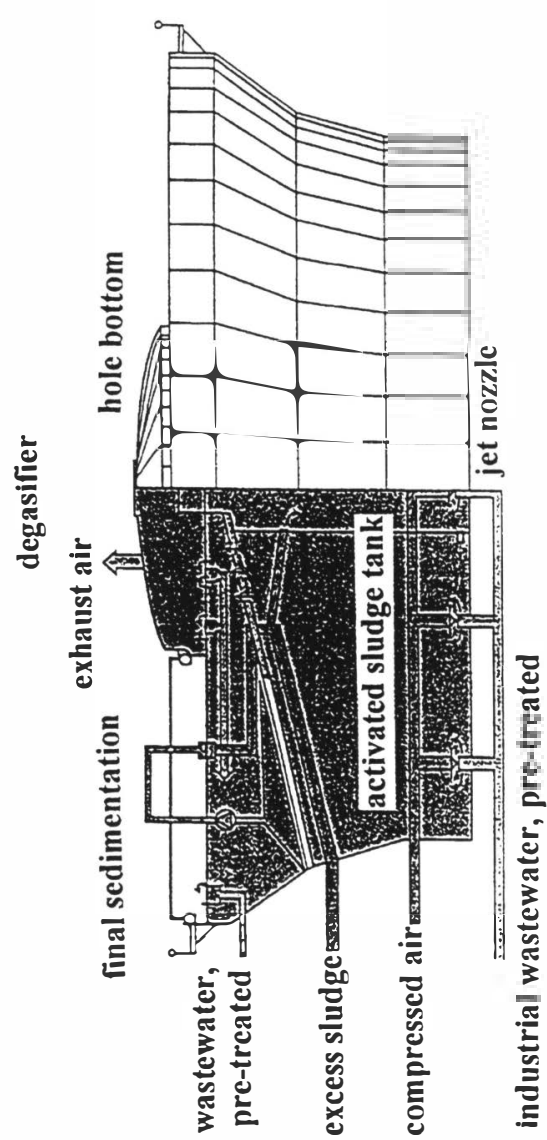

Fig 3:Diagram of a BIOHOCH-reactor at the Sewage plant bitterfeld wolfen [7]

The efficiency of the elimination process is reflected by the following figures: COD with phosphorus of $90 \%$ and for nitrogen with more than $50 \%$.

\section{Project Belzig}

While the modernisation of the sewage system in most cities and large towns is either complete or near completion, it has only first began in some of the small towns. In the villages the sewage treatment situation has in part remained as it was in 1990. A good example is the community of Belzig in Brandenburg. 
Belzig is a small town inhabited by approximately 8000 people. Within a radius of about $15 \mathrm{~km}$ there are sixteen villages each with an inhabitance of 100 to 700 and it's own administration. The local structures are shown in fig. 4 . The region is, with the exception of Belzig that has a small commercial trading area, agricultural. There's a old sewage plant in Belzig that's in need of repair. The sewage sludge is collected from the surrounding villages by road. In Belzig it's self there's a sewerage that also needs modernising.

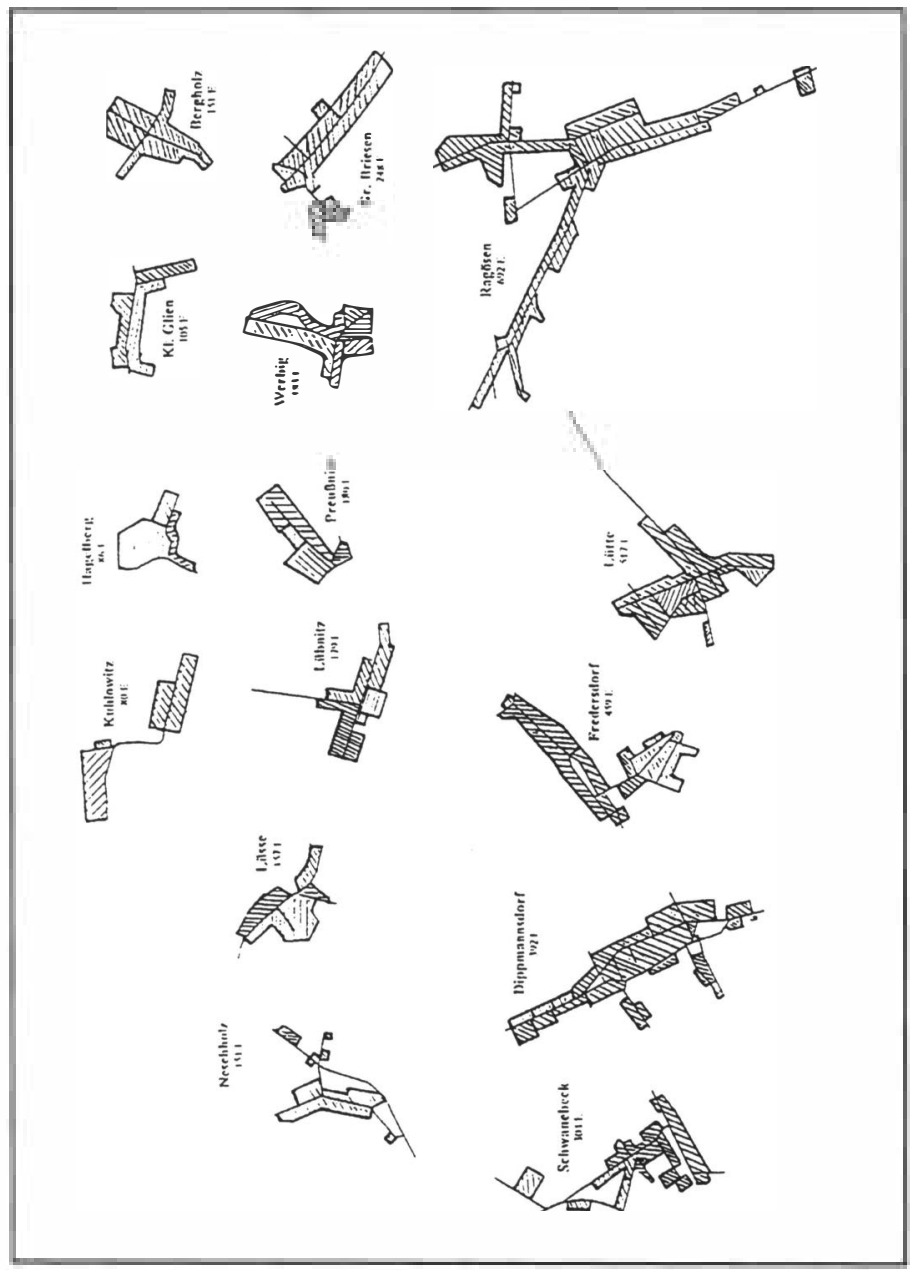

Fig. 4: Local structures of the villages belonging to the community of Belzig 
Action was slow, due to the administration not being quite clear as to whom is responsible for the modemisation of the sewage plant. Owing to the future financial burden, there was a general reluctance to take any steps towards modernisation and a subdued environmental interest to protect the ground and surface water. There was nobody in the administration who was willing to put pressure behind development. A change came in 1995 when the communities were obliged by Brandenburg state legislation to derive concepts for sewage treatment and disposal.

When a engineering office was commissioned with working out a sewage disposal concept it proved difficult to gain consensus between the 16 villages to cooperate on a mutual concept. The acquisition of the necessary basic information to work with was a further problem. Plans and knowledge of the existing constructions and their condition could only be partly acquired, on account of unknown or undefined responsibilities of civil servants. With considerable effort a concept was completed within only half a year.

Because there was no proper existing sewerage and treatment plant, there was opportunity to examine a whole range of solutions and alternatives. There were 7 alternative methods of sanitary waste water drainage to choose form: a conventional combined sewer system, a conventional separate sewer system, a modified natural fall sanitary sewer system, pressure pipe and subpressure pipe systems. The rain water drainage is achieved on the surface via ditches and depressions, if it is not part of the combined systems mentioned above.

The modemisation and incorporation of the existing household catch pits offers several alternatives when connecting them to $2,3,7,10$ or 14 different sewage treatment plants, which also present different transport distances by road.

All the altematives were representatively drafted and technically and economically under consideration of depreciation, interest rates and operational costs evaluated. Obviously the drainage of rain water in an open system in an rural area such this is much cheaper than in a enclosed rainwater drainage system.

The concept of retaining the catch pits proves to be the most uneconomical although it is clearly the one involving the least investment. A considerably modified gravity line sanitary system with pipes running mainly along municipal property has been decided upon. In exceptional cases at certain low levels the catch pits will remain. The main characteristics of the modification are as follows:

Choice of route: Conventionally a sewerage runs alongside roads and only on property owned by the council. Costs can be reduced by laying the pipes below none made up surfaces, such as below verges, below ditch embankments or on private ground, thus saving the expense of reinforced ditch fillings. The difficult access to private property and the negotiations with owners are a disadvantage. Each proprietor has to agree, compensation must be paid, and entries made in the land register. 
Minimum nominal diameter: Because of the danger of stoppages the smallest standard diameter is set at DN 250. Under circumstances DN 200 can also be used. The choice of a nominal diameter of DN 150 is also feasible providing the minimum bed gradient of $1: \mathrm{DN}$, equivalent to $0.67 \%$, is maintained. Compensating for $50 \%$ external water such a system would be adequate for 1200 inhabitants. While the danger of a stoppage increases with a smaller nominal diameter it decreases with higher flow velocity, which occurs with well filled pipe cross sections. Recently constructed systems of this dimension have not shown any significant problems.

Reach: According to German technical norms the reach of pipes with small nominal diameters should be between 50 and $70 \mathrm{~m}$. These lengths are derived from old fashioned methods of cleaning with a winch. Modern flush vehicles have hose pipe lengths of upto $200 \mathrm{~m}$, with which to rinse out clogged up pipes, and video cables of equal length. Vehicles operating at waste deposit land fill sites clean drain pipes of upto $800 \mathrm{~m}$ long. When the amount of manholes are reduced less external water can penetrate into the system through the cover holes. The lengthening of the reaches to $150 \mathrm{~m}$ is perfectly reasonable provided two inexpensive vent pipes are installed to allow for the necessary ventilation.

Depth of excavation: The connection of basement drainages to the sanitary sewerage by natural fall is not absolutely necessary, so that the street sewerage pipes can be laid in shallower beds. The basement drainage can be accomplished using drainage pumps, whereby reflux valves according to the German industrial norm (DIN) of 1986 are to be installed.

Vent pipes: Investments can be reduced by replacing man holes with vent pipes. The use of vent pipes with minimum nominal diameters of DN 400 to DN 450 allow easy entry of cleaning and inspection apparatus. Vent pipes should not be placed below road surfaces but below neighbouring surfaces, that don't have to withstand substantial pressure, e.g. verges, bike and foot paths.

Use of plastic pipes: Rigid drainage pipes are made of concrete, fibre cement, stone ware or ductile cast iron. Pliable alternatives are pipes made of PVC and PE. Their qualities are: chemical resistance, very high abrasional strength, light weight, easily workable, smooth internal surface, pipe lengths of upto $20 \mathrm{~m}$, resulting in less connections and less cost. The disadvantages are low strength e.g. low hardness and low tensile strength, resulting in deformation of cross sections, which reduces the hydraulic efficiency and causes problems by later connections. PVC possesses a lower chemical resistance towards certain solvents than PE, and PE needs to be protected against UV-light.

Gradient pressure conduit: Delivery pipe-lines with few or no side connections and having enough surface gradient are cheaply constructed as gradient pressure conduits. They can be operated with pump stations if needed. The advantages are that they don't require a constant bed slope and high and low levels below the hydraulic pressure gradient are acceptable. Also the manholes, in this case control and flushing shafts, can be placed further apart. 
Most of these modifications are not described by German norms. At present there's a intensive discussion about the risks and liability of engineers, who diviate from the standards. The latest state ordinances permit these modifications.

The results of the economic comparison are displayed in the following table. The concept of a modified gravity line system exclusively for sanitary effluent is recommendable.

Table 12: Results of an economic COMPARISON of alternativ sanitary drainage systems for the community of Belzig [6]

\begin{tabular}{|l|c||c|}
\hline type of construction & investment & Projektkostenbarwert \\
\hline \hline conventional natural fall & $100 \%$ & $55 \%$ \\
\hline modified natural fall & $50 \%$ & $54 \%$ \\
\hline pressure sewerage & $62 \%$ & $89 \%$ \\
\hline subpressure sewerage & $65 \%$ & $100 \%$ \\
\hline
\end{tabular}

A comparison of the various drainage systems shows, when accounting for the cost of the pumping stations, delivery pipe-lines and sewage plants, the concept of 7 treatment plants to be the most favourable. On account of too distant or too smaller recipient waters, the treated discharge will have to be reinfiltrated, to the effect that, in spite of the small dimensions involved, the sewage will need to be extensively purified. The „container sewage treatment plants“, that are in discussion at the moment, are of low cost but have inadequate process stability and frequently display insufficient neutient elimination. They would in this case only come as a transitional solution in question. At present, in the Federal Republic of Germany there are different institutes that are testing biological pond and plant water treatment system with improved nitrogen and phosphorus elimination. Such system are also planed for the community of Belzig.

Although the most economic solution has been chosen political problems are expected, because, in spit of the project being subsidised by the state or Europe, part of the cost will have to be paid by the citizens, who are often under paid or unemployed.

\section{PROSPECTS}

It is a well known fact that with the financial help the quality of the surface waters has been considerably improved. But inorder to achieve the requirement of the European regulations substantial effort particularly from the middle and small towns will have to be made. Especially the diffuse contamination remains a problem. The discussion over the most economic methods will continue. From a 
technical point of view, the more economic methods, which usually diviate from conventional techniques, will gain popularity at the expense of a lower standard.

\section{Thesaurus}

Abwasserreinigung, DDR, Deutschland, Elbe, neue Bundesländer, Nordsee, Ostsee

\section{LITTERATURE}

[1] NN, Abwasserzielplanung für Brandenburg. Brandenburger Umweltjournal, Heft 20, August 1996.

[2] NN: Dessauer Kläranlagen GmbH, Festschrift 2. Juni 1997, Inbetriebnahme der Dessauer Kläranlage

[3] NN: Gewässergütebericht 1996 des Landes Sachsen-Anhalt

[4] BUNDESMINISTERIUMrFÜR UMWELT, NATURSCHUTZ UND REAKTORSICHERHEIT: Eckwerte der ökologischen Sanierung in den neuen Bundesländern, November 1990

[5] BUNDESUMWELTMINISTERIUM: Aktuell, Umweltschutz - Im Osten viel Neues, Informationsschrift, 1995

[6] DR. FRIMAN UND PARTNER: Amt Belzig, Landkreis PotsdamMittelmark, Schmutzwasserbeseitigungskonzept und Freistellungsunterlage gemäß BbgWG, 1996 (unveröffentlicht)

[7] GKW: Gemeinschaftsklärwerk Bitterfeld-Wolfen, 1995

[8] GRÜBEL: Persönliche Mitteilungen vom 26.08.1997 über das Klärwerk Gotha

[9] HANSEN, J.; STEINMETZ, H.; ZETTL, U.: Betriebsergebnisse und Auslastung der Kläranlage Gotha - zwei Jahre nach der Inbetriebnahme. awt 2/95

[10] KÄMMER, G.; MÖLLER, F.-W.: Kläranlage Gotha - Ein erfolgreiches Konzept für eine moderne Abwasserbehandlung. . In: Berichte der ATV, Heft 43, 1994, S. 1005 - 1019

[11] LÜTZNER, K.: Abwassersituation in den neuen Bundesländem am Beispiel Dresden. In: Berichte der ATV, Heft 41, 1992, S. 277 - 291

[12] MACHOLD, H.; GEBHARD, K.; LÜTZNER, K.: Planung für zentrale und dezentrale Abwasserbehandlungsanlagen in Ostdeutschland; 24. Essener Tagung, 24.04. - 26.04.1991 in Dresden

[13] MECKLENBURG-VORPOMMERN: MINISTERIUM FÜR BAU, LANDESENTWICKLUNG UND UMWELT DES LANDES MECKLENBURG-VORPOMMERN: Schreiben vom 09.12.1996 an alle Wasserbehörden des Landes, betr. Maßnahmen und Ergebnisse des Gewässerschutzes in Mecklenburg-Vorpommern 
[14] MINISTERIUM FÜR RAUMORDNUNG, LANDWIRTSCHAFT UND UMWELT DES LANDES SACHSEN-ANHALT: Persönliche Mitteilungen vom 15.08.1997

[15] MINISTERIUM FÜR UMWELT, NATURSCHUTZ UND RAUMORDNUNG DES LANDES BRANDENBURG: Abwasserentsorgung in Brandenburg, 1996

[16] WASSER- UND ABWASSER-ZWECKVERBAND GOTHA UND LANDKREISGEMEINDEN: Verbandskläranlage Gotha, 1993 